\title{
An Exploration of the Aesthetics of Dalit Trauma In Mulk Raj Anand's UNTOUCHABLE
}

\author{
BIANCA CHERECHÉS \\ University of Zaragoza \\ bc@unizar.es
}

Received: 15-09-2018

Accepted: 03-01-2019

\begin{abstract}
The Dalit community has suffered generational, multi-faceted and institutionalised discrimination as a result of the implementation of the Hindu caste system in the Indian society for religious and political reasons. This casteist practice has left a clear mark of social division and inequality and has severely damaged this community's identity. Mulk Raj Anand, one of the pioneers in addressing this issue, offers a glimpse of what being a Dalit or untouchable entailed in pre-independent India in his short but intense novel Untouchable, in which he narrates episodes of verbal and physical violence and recurrent inter- and intra-caste discrimination, thus depicting the traumatic existence of this oppressed community. Therefore, the aim of this paper is to delineate the aesthetics of Dalit trauma as represented in this short novel and to determine the extent to which this model complies with the pre-existing paradigms of trauma theory or if they need to be reconsidered.
\end{abstract}

KEYWORDS: Dalit, untouchability, trauma theory, casteist trauma, insidious trauma, postcolonial literature.

\section{RESUMEN Una exploración de la estética del trauma Dalit en Untouchable de Mulk Raj Anand}

La comunidad Dalit ha sufrido discriminación generacional, polifacética e institucionalizada debido a la implementación del sistema de castas hindú en la sociedad india por razones religiosas y políticas. Esta práctica casteista ha dejado una evidente huella de división y desigualdad social y ha dañado seriamente la identidad de esta comunidad. Mulk Raj Anand, uno de los pioneros en abordar este asunto, ofrece un esbozo de lo que significaba ser un Dalit o intocable en la India pre-independiente en su breve pero intensa novela Untouchable, en la que narra episodios de violencia verbal y física y continua discriminación inter- e intracastas, describiendo así la existencia traumática de esta comunidad oprimida. Por tanto, el objetivo de este artículo es delinear la estética del trauma Dalit representado en esta breve novela y determinar hasta qué punto este modelo cumple con los paradigmas ya existentes de teoría del trauma o si estos necesitan ser reconsiderados.

Palabras Clave: Dalit, intocabilidad, teoría del trauma, trauma casteista, trauma insidioso, literatura postcolonial. 


\section{INTRODUCTION}

Mulk Raj Anand's short novel Untouchable (1935) describes one day in the life of Bakha, an 18year-old Indian outcaste sweeper, through whom the reader can catch a glimpse of what being an outcaste in India implied in the 1930s. Thus, the novel's most prevalent topic is 'untouchability', a historically developed caste-segregation practice in Indian society, based on the Hindu caste system and endorsed by the Hindu religion. Under the caste system, each person is born into one of the four main social castes (Brahmins, Kshatriyas, Vaishyas, Shudras ${ }^{1}$ ) or rather belongs to the outcastes group who are considered avarna. This fifth varna contains many Indian oppressed groups such as the Scheduled Castes, the Scheduled Tribes or adivasis, and the untouchables to name some, and the term 'Dalits' — used for the first time with a political connotation by the social reformer Jyotirao Phule - is the umbrella term employed in order to homogenise these heterogeneous but oppressed Indian groups. One of the outcomes of this social stratification, according to which all are born unequal and one's status is determined by an inherited profession, is the historical dominance of the high castes over the lower castes - including the outcastes or Dalits - and the social implementation of the concept of untouchability with all of its corollaries on the lower castes.

The Dalit community has therefore endured centuries of subalternity, marginality and socioeconomic inequality, and has been subsequently deprived of any kind of rights or voice, being thus thrust to the very bottom of Indian society. Anand, by means of writing this short and intense novel, which narrates the array of discrimination and violence suffered by Dalits in a single day, has provided this voiceless and downtrodden community with voice and has thus changed the usual high-caste focalisation of the Indian narrative from a high to a low-caste perspective.

Nonetheless, this novel and its bestowal of voice to the social outcastes may certainly raise issues of authenticity, entitlement and representation since Anand was an educated man born in a Kshatriya family. Due to this, many critics have questioned the legitimacy of a high-caste male to write about

\footnotetext{
${ }^{1}$ The caste system divides Hindus into four main categories: Brahmins (who were mainly teachers and intellectuals and are believed to have come from the head of Brahma, the Hindu God of creation); Kshatriyas (the warriors and rulers, who supposedly come from his arms); Vaishyas (the traders, who were created from his thighs); and Shudras (who came from Brahma's feet and did all the menial jobs). These main castes were further divided into about 3,000 castes and 25,000 sub-castes, each based on their specific occupation. Outside of this Hindu caste system were the outcastes - the Dalits or untouchables. (Chandra, 2005)
} 
the outcastes and concur with the belief that "only a Dalit by birth can have the sensitivity and experience to be a genuine Dalit writer" (Kumar, 2010: 147). Others have even stressed that "nonDalits cannot claim to understand and write about these issues" (Valmiki \& Mukherjee, 2003: xxxiv) thus highlighting the importance of Dalits airing their own marginalised voices instead of depending on the representation of an intermediary.

Nevertheless, in his afterword to Untouchable (Anand, 2014: 142-43) E. M. Forster claims that,

Untouchable could only have been written by an Indian, and by an Indian who observed from the outside [...] no Untouchable could have written the book, because he would have been involved in indignation and self-pity. Mr. Anand stands in the ideal position. By caste he is a Kshatriya, and he might have been expected to inherit the pollution-complex. But as a child he played with the children of the sweepers attached to an Indian regiment, he grew to be fond of them, and to understand a tragedy which he did not share. He has just the right mixture of insight and detachment [...].

Hence, although the representation of the entire Dalit community by a high-caste writer may indeed be problematic and questionable to the extent to which several perspectives intertwine and must be taken into consideration, Anand's novel — published as early as 1935- was undoubtedly groundbreaking as, despite being an outsider and providing an etic rather than the supposedly desirable emic perspective on this thorny issue, it somehow paved the way for the emergence of the Dalit movement years later. Moreover, some of the issues Anand tackles in the novel, namely the inter/intra-caste discrimination suffered by Dalits, their cyclical and generational oppression, the burden of untouchability, the role of religion and the need for social change, to mention but some, are still alive and kicking in today's India.

\section{TRAUMA IN UNTOUCHABLE}

Although the novel seems to depict Bakha's own experience and perspective, not only does it portray the life of an individual young low-caste sweeper, but it simultaneously becomes an account of the entire Dalit community and their collective experiences. For that matter, the concept of untouchability and the subsequent multi-faceted discrimination towards this heterogeneous oppressed community is at its core. Thus, when dealing with these issues the concept of trauma automatically comes to mind as Dalits can undoubtedly be regarded as potential trauma victims. 
Consequently, the aim of this paper will be to delineate several reasons why Untouchable, being part of Dalit literature, should be considered as a trauma text by exploring in detail its narrative elements, motifs and themes with the help of some well-known trauma theories. In order to do this, it is first of all necessary to reflect upon the very concept of trauma and the several definitions of it given by critics, so as to be able to determine the extent to which the trauma depicted in this novel fits into classical Eurocentric notions of trauma, or else if these need to be reconsidered and adapted in order to properly engage with the critical analysis of Dalit texts.

In Untouchable, Anand narrates a day full of violent events on account of both inter and intra-caste abuse and hierarchy, since one of the Hindu caste system's effects is precisely the stratification of Indian society into five main social groups —originally called Jats or Jatis until the arrival of the British who further referred to them as 'castes' - and their subsequent division into several subcastes. Such is the case of the fifth varna or outcaste community, which is equally segmented into multiple social strata according to their members' inherited professions - leather-workers, washers, scavengers, and sweepers, to name but a few- leading to a superior status phenomenon between the outcastes themselves and the avoidance of physical contact with the lower strata, which Raj Kumar (in J.K. Abraham and J. Misrahi-Barak, 2016: 144) explains as follows:

Following the Hindu caste structure, there are rigid internal hierarchies among Dalit communities themselves [...] Due to such rigid caste practices, intercaste eating and intercaste marriages are still not allowed between any two Dalit communities [...] This indicates that Dalits cannot come together to voice their grievances. They are split asunder and broken into several pieces.

Hence, this internal ramification caused social inequalities and recurrent verbal and physical abuse which, apart from denoting the brutality that surrounded the outcastes, also adds ironic and comedic effects to the narrative. In fact, the violence among the outcastes invites us to consider the nature of the language and behaviour available to them and the possibility of their being sentenced to live perpetually in a hostile linguistic and social climate:

She [Gulabo, a washerwoman, thus upper low-caste] thought herself superior to every other outcaste, because she claimed a high place in the hierarchy of the castes among the low castes [...]. Sohini [Bakha's sister] being of the lowest caste among the outcastes would naturally be looked down upon by Gulabo [...]. 'You ought to be ashamed of yourself! You bitch! You prostitute! Wanton!' (17) 
However, one episode in particular is highlighted in the narrative: Bakha, after cleaning the latrines in the British cantonment and heading towards the city temple to continue performing his cleaning duties, forgets to announce his presence by shouting "Posh, keep away, posh, sweeper coming [...]!" (41, emphasis in the original), and accidentally touches a high-caste Hindu passer-by. He is slapped by the high-caste man for his irresponsibility and negligence, and is in addition publicly shamed in front of a crowd that has gathered around him. Thus, Bakha has to pay the price for transgressing his limits and not obeying the established space/power relationship by enduring both physical and verbal abuse, and he recalls the event once and again during the rest of the day with a mixture of self-pity, self-incrimination and rage, to the point that he cannot help but remain alert and afraid of what might happen next.

According to Cathy Caruth, who based her theories on Freud's Beyond the Pleasure Principle (1919) and the definition of Post-Traumatic Stress Disorder (PTSD) given in the Diagnostic and Statistical Manual (DSM III-R) of the American Psychiatric Association (American Psychiatric Association, 2000: 467-8), an event is traumatic when it is outside the range of usual human experience and, precisely because of its overwhelming nature, can lead to numbness or a period of latency or belatedness after which the victim is haunted by the traumatic event in the forms of intrusive thoughts, nightmares, hallucinations, or can even develop an increased arousal to (and avoidance of) stimuli recalling the event (Caruth, 1995: 3-4).

If we stick to Caruth's definition of trauma as implying disruption, compulsive repetition, psychic numbing and heightened physiological arousal, we can see that Bakha — or the Dalit community in general, as he appears as a representative of the whole community in the novel - apparently does not suffer all these symptoms. First and foremost, his trauma does not consist of a single and identifiable event that breaches his usual life although the slap he received in the city has undoubtedly affected him: rather, he is subjected to a non-stop traumatic existence filled with recurrent physical and verbal abuse such as “Oh, Bakhya! Oh, you scoundrel of a sweeper's son! [...] Why aren't the latrines clean, your rogue of a Bakhe!” $(8,9)$. Pramod K. Nayar (in J.K. Abraham and J. Misrahi-Barak, 2016: 322), for instance, highlights that "the nature of caste oppression means that it cannot simply be deemed a horrific event but must be treated as a traumacontinuum". In other words, the kind of experiences with which the outcastes have had to comply for centuries have left obvious and perennial marks on their lives and psyches although they may 
not be aware of their trauma: "Heredity had furrowed deep grooves in his soul [...] The cumulative influence of careful selection had imprisoned his free will in the shackles of slavery" (81).

Furthermore, what Caruth defines as a 'shattering of prior forms' (Caruth, 1995: 137) cannot be applied to Dalits because, as the novel describes, Bakha, like the rest of the outcastes, was very much aware of the possibility that this could happen given his low social status and its implications ("He was used to being spoken to roughly" (37)), and the 'defiling' nature of his presence was embedded in his memory: "Of course, I polluted the child. I couldn't help doing so. I knew my touch would pollute" (101). Therefore, it is difficult to talk about unexpectedness in the Dalits' case.

As regards belatedness, Caruth states that "for history to be a history of trauma means that it is referential precisely to the extent that it is not fully perceived as it occurs" (Caruth, 1995: 8), thus pointing to a distortion of the traumatic event. However, in Bakha's case that period of latency is apparently imperceptible, as:

[...] in his mind arose dim ghosts of forms peopling the scene he had been through. The picture of the touched man stood in the forefront, among several indistinct faces, his bloodshot eyes [...] his abuse; and there was the circle of the crowd, jeering, scoffing, abusing, while he himself stood with joined hands in the centre. (41)

and he even ponders on the event right after its occurrence:

$[\ldots]$ there was a smouldering rage in his soul [...] when the recollection of some abuse or rebuke he had suffered kindled a spark in the ashes of remorse inside him. [...]'Why was all this?' he asked himself [...] 'Why was I so humble? [...] Why didn't I shout to warn the people of my approach? [...] Why are we always abused? [...] Because we are sweepers.' (41-42)

Even so, he does experience some numbness or physical paralysis when the event takes place, as he is unable to defend himself or to instantly reply to the accusations: "Bakha stood amazed, embarrassed. He was deaf and dumb. His senses were paralysed.” (37). In addition, he remains hypervigilant for the rest of the day while continuing with the performance of his duties: "He noticed that the thumping of his heavy feet on the ground excited too much attention [...] He became conscious that people were looking at him." (43), as if that public humiliation was a turning point in his life and marked him forever. 
Thus even if Bakha — and Dalits in general — does not exhibit all trauma symptoms as Caruth and Freud's trauma paradigm describes them, it does not imply that Dalits are not trauma victims. In fact, many critics have accused this trauma paradigm of being a cultural construction with a narrow Eurocentric perspective, as the term 'trauma' was mainly coined as a result of analysing western victims. Laura S. Brown goes as far as to assert that the human experience mentioned in these classical definitions of trauma often makes reference to "white, young, able-bodied, educated, middle-class, Christian male human experience" and that "trauma is thus that which disrupts these particular human lives, but no other" (in Caruth, 1995: 101). In other words, that both female and whole non-western perspectives have been totally ignored by the classical trauma interpretation. This point of view explains why many critics have emphasised the need to re-examine and expand the early monolithic trauma paradigm so as to integrate and better address non-western instances of trauma and loss, such as the transgenerational caste-based trauma.

Regarding the idea of belatedness or latency for instance, Joshua Pederson argues that "traumatic amnesia is a myth" since, although "the memory of the event(s) can be altered in the aftermath, it cannot be altogether forgotten" (Pederson, 2014: 333-353). This idea defends that trauma is, after all, memorable and describable as it is the case of Bakha, who immediately after the event in the city is able to recall it and reflect on it, and his sister Sohini and his father Lakha who are able to verbalise the abuses they endure: "'Bhangi! (Sweeper) [...] Chandal! (low-caste) [...]. And then you join hands and hold my feet and say you will become my slave for ever. You have polluted hundreds of rupees worth of medicine." (69)

Concerning the belief that trauma stems from a shattering event, Kai Erikson argues that "trauma can issue from a sustained exposure to battle as well as from a moment of numbing shock, from a continuing pattern of abuse as well as from a single searing assault" (in Caruth, 1995: 185). Therefore, facing harassment on a daily basis that is seen as divinely ordained — both Manusmriti and Rigveda seem to sanction it (Valmiki \& Mukherjee, 2003: xxii) —and is lived as institutionalised, as is the case of Dalits such as Bakha and Lakha, is undoubtedly traumatic and affects the victims to such a point that their perception of reality is deeply distorted: "No, no,' said Lakha [Bakha's father]. 'They are really kind. We must realize that it is religion which prevents them from touching us.' He had never throughout his narrative renounced his deep-rooted sense of inferiority and the docile acceptance of the laws of fate." (70). Moreover, the trauma the Dalits 
suffer has different origins on account of the attitudes of superiority and discrimination concomitant to the social stratification, leading to a generalised passivity: "This forgetfulness or emptiness persisted in him over long periods. It was a sort of insensitivity created in him by the kind of work he had to do, a tough skin which must be a shield against all the most awful sensations." (13)

Furthermore, many critics stress that, when dealing with trauma, the socio-cultural component must necessarily be taken into account, since events are not inherently traumatic and it is, rather, the effect they produce on people that gives them the quality of trauma; or as Caruth puts it, "the pathology of trauma cannot be defined by the event itself [...] which may or may not traumatise everyone equally" (Caruth, 1995: 4). Such is the case in Untouchable since Anand offers two perspectives on the Dalit trauma: the young and revolutionary untouchable who is reflective and aspires to receive an education and become a sahib, as represented by Bakha; and the old, obedient and resigned figure who has internalised his lot, as represented by his father Lakha. The narrator depicts the fact that what for Bakha is traumatic — namely the slap he received in the city — for his father Lakha is simply part of his inexorable oppressed condition, another daily abuse to add to the endless list: “No, no, my son, no,' said Lakha [...] 'They are our superiors. One word of theirs is sufficient to overbalance all that we might say. They are our masters. We must respect them and do as they tell us." (68). Therefore, apart from proving the extent and intensity of the casteist generational oppression to the point where many Dalits ended up believing in their own vulnerability and inferiority and perpetuating their fate, Anand also depicts its variations in magnitude across different generations and different outcaste strata.

Dalit trauma is thus the main issue in the novel's agenda, since the multi-layered inter/intra-caste inequalities are extensively portrayed to highlight how Dalits were constantly reminded of their inferior and powerless position. Throughout the novel, Anand shows how different elements, religious figures and places in the city - the public well, the temple, the high-castes' private houses and even the city streets - prompt and reinforce Dalits' hypervigilance, as they constantly remind them of their inferiority and physical and moral limits, the very source of their trauma. For instance, when performing his cleaning duties at the city temple, Bakha is overwhelmed by the temple and everything it stands for: "not daring to look beyond the gate with the overt, lifted eye of the ordinary man $[\ldots]$ but like a slave stealing an enquiry into the affairs of his master." (47) 
Another aspect to be considered in the novel's representation of trauma is religion, as many of the traumatic incidents described in the novel — having to live on leftover food from the upper-castes, not being allowed to enter the temples, and having to live on the outskirts of villages - seem to be religiously sanctioned. Moreover, since Hinduism was intertwined with the caste system and untouchability, many Dalits saw religious conversion as an escape route and as a means to seek dignity and equality. Yet discrimination and inferiority clung to them like a shadow, as Anand argues when he stresses in the novel that the few Hindustani words that the Christian sahibs typically learnt were the likes of "jao" (go away), "jaldi karo" (be quick), "sur ka bacha" (son of a pig) and "kute ka bacha" (son of a dog) (108).

Therefore, in the case of the Dalit community trauma takes place both in the private and public spheres, in clear contrast with the western notion of trauma as being usually paired with private spaces, as abuses typically occur behind closed doors and away from the public gaze. On the contrary, Dalit texts often refer to abuses inflicted openly in the streets by members of the upper castes, as it is the case of the event in the city, apart from the recurrent domestic violence as when Bakha is abused by his father: "'You lover of your mother,' his father had abusively said to him [...] 'Get up, you son of a pig, you illegally begotten.’” $(4,6)$

Consequently, trauma becomes a quintessential part of Dalits' 'normal' life. This is what Maria Root (Root, 1989, 1992 ctd. by Laura S. Brown) defined as insidious trauma or "the traumatogenic effects of oppression that are not necessarily overtly violent or threatening to bodily well-being at the given moment but that do violence to the soul and spirit" (in Caruth, 1995: 107). Dalits suffer from constant hypervigilance and fear of contaminating the higher-castes, wishing to avoid being harassed, beaten or punished, which has inevitably resulted in a low self-esteem, lack of confidence, helplessness and self-incrimination, among many other things:

'That comes of not looking after one's work. [...] I should have seen the high-caste people in the street.' [...] Like a ray of light shooting through the darkness, the recognition of his position [...] dawned upon him. [...] It was all explicable now. [...] 'I am an Untouchable!' [...] he repeated the words in his mind. (41-42)

Moreover, as Laura S. Brown goes on to argue, the insidious trauma and its symptoms can be intergenerational "when membership in that group means a constant lifetime risk of exposure to 
certain trauma [...], those for whom insidious trauma is a way of life" (in Caruth, 1995: 108), thus damaging their whole community and collective identity.

As for the idea of collective identity, Roger Luckhurst adds that although "at first PTSD was only attributable to those directly involved, [...] 'secondary' victim status now includes witnesses, bystanders [...] [and] relatives caught up in the immediate aftermath" (Luckhurst, 2013: 1). In tune with this, the entire Dalit community can be regarded as trauma victims as, despite the nuances in the discrimination they suffer, they share a collective memory based on the generational caste system inequity that pervades them all. Furthermore, several critics have made references to the centripetal and centrifugal social effects of trauma, meaning that Dalits feel estranged but at the same time share exposure to the same pain and atrocities, which can eventually lead to the development of a sense of fellowship, a collective type of trauma.

In the case of the Dalit community there is a conflation between individual and collective trauma because, while their experiences are personal and specific, the trauma they face has a cultural and collective dimension that has clearly affected their social identity. Moreover, their trauma is multidimensional since it is not only the caste system — inter/intra-caste inequality - that has discarded and neglected them, but also religion, gender and class: religion because especially in the past many upper-caste Hindus have played a role in their abuse, and also because, even after many of them converted to other religions in order to escape the burden of casteism, they still had to face discrimination on account of their status as untouchables (Roy, 2014: 131); gender because Dalit women have been widely abused, not only by the upper castes, but also by the men from their own communities; and class because the caste system is classist and endogamous at its core.

Taking into account Dominick LaCapra’s distinction between transhistorical/structural trauma what he identifies as 'absence' — and historical trauma — i.e. 'loss' — Dalits might be said to suffer from the transhistorical/structural type as in their case it is difficult to reduce trauma to a single identifiable event; their traumata are often the consequence of multiple immemorial factors, such as religion, power struggles and social and economic causes. In fact, for these cases LaCapra suggests a blurring or conflation between absence and loss as he argues that "absence [...] is perhaps necessarily identified with loss [...], even figured as an event or derived from one" (LaCapra, 2001: 48-49), and adds that "in converting absence into loss, one assumes that there was [...] some 
original unity, wholeness, security, or identity that others have ruined, polluted, or contaminated" (LaCapra, 2001: 58). In this case, while the origins of the caste system are still debated and unclear, the Rigveda and the Manusmriti — the two most important foundational texts in Hinduism — can be regarded as its most probable sources. In any case, Hinduism has held the caste system in place for centuries and has negatively construed Dalits' identity.

In short, Dalit trauma, like those described in many postcolonial texts, does not seem to fit into the restrictive Eurocentric notions of trauma unless some adjustments are made. As a matter of fact, Anne Whitehead claims that "trauma fiction actually borrows from postcolonial fiction in its use of stylistic devices, its concern with the recovery of memory, and its interest in bringing marginalised and silent or silenced stories to the public awareness" (in Herrero and Baelo-Allué, 2011: xv). When it comes to analysing whether Untouchable's stylistic devices echo those of conventional trauma texts, it is clear that the novel contains no repetitive structures or anachronisms, that is, the reader does not deal with an experimental or aporetic text. However, Anand does play with temporality by means of introducing numerous flashbacks — or analepses - mostly related to Bakha's childhood memories as a comfort source. The reason why the novel's aesthetic differs from those of conventional trauma texts in which trauma is clearly reenacted could be the fact that it is not an autobiographic piece, thus endowing the author with enough distance to be able to tackle the issue differently.

This idea of the necessary distance to enable one to speak - the argument E. M. Forster (2014) used to defend Anand's legitimacy as the author of a Dalit text - is linked to the idea of 'collapse of witnessing' as put forward by Dori Laub (in Caruth, 1995: 6-7). After facing the horror of discrimination and abuse in the city, Bakha is haunted by the event and feels the compulsive need to share it, but instead of receiving compassion and empathy from his father, he learns that his father chooses to take the oppressor's side. Thus, in Bakha's case, the fact that he does not have enough time to sort out and fully process the event and speaks too soon about it, can be connected with Mallarmé's concept of 'precocious testimony' or the "speaking in advance of the control of consciousness" (in Caruth, 1995: 27-29). Furthermore, since he is 'inside' the event and subsequently unable to fully grasp it - he does not have the required distance from it - he can be considered a rather unreliable witness especially because he does not recount the whole shattering event to his father and friends, but only fragments of it. 
By the same token, it can be said that in the Dalits' case there is a generalised collapse of witnessing as every testimony they provide is biased or contaminated in one way or another on account of the endurance of casteist oppression for centuries, which has resulted in the internalisation and acceptance of their subhuman status and in granting the caste system a sort of legitimacy. However, as Dori Laub argues, "it was unconceivable that any historical insider could remove herself sufficiently from the contaminating power of the event so as to remain a fully lucid, unaffected witness, that is, to be sufficiently detached [...]. No observer could remain untained [...] and provide an independent frame of reference" (in Caruth, 1995: 65-66).

Regarding the idea of precocious testimony and the compulsive need to tell as part of the burden of witnessing a traumatic event, LaCapra says that "when the past becomes accessible to recall in memory, and when language functions to provide some measure of conscious control [...] and perspective, one has begun the arduous process of working over and through trauma" (LaCapra, 2001: 90). For her part, Shoshana Felman points to the 'remedial quality' of narrative (in Caruth, 1995: 16) which means that, by making an effort to articulate what actually happened to him, Bakha has already begun working through his trauma, although precociously and not receiving the empathy he expected.

The generational discrimination and constant abuse inflicted upon the Dalit community have left strong marks at a personal level (many of them suffer from anhedonia - the impossibility or inability to experience pleasure - and alexithymia — the inability to identify and describe emotions in the self), but they have also damaged the entire community. Kai Erikson coined the concept of 'corrosive communities' (in Caruth, 1995: 189) as another consequence of traumatic events, as they inevitably create gaps between the members of a community, as is the case of the Dalit community, which is a victim of the Indian casteism characterised precisely by the existence of different social layers that suppress and oppress one another. Erikson even comments on the feeling of loss of natural immunity to misfortune that results in the victims' alertness and apprehension: "the horrible prospect of all the future days of service in the town and the insults that would come with them." (66). Moreover, based on Erik Erikson's idea that from a psychological point of view it would be ideal to embrace the past and be at peace with oneself, Henry Krystal highlights that accepting the terrors inflicted in the past would somehow mean granting the perpetrators a victory and rejecting 
their right to retaliate, which can only generate ever-increasing indignation and rage (in Caruth, 1995: 83-85), as is the case with Bakha who dwells on his passivity: "Why was I so humble? I could have struck him!” (41).

Other critics talk about a fidelity to trauma or resistance in order to work it through, a phenomenon that LaCapra calls 'founding trauma' (LaCapra, 2001: 23), clearly pointing to the paradoxical power of trauma as an identity builder. In fact, LaCapra goes as far as to assert that this can even lead to "a belief in one's privileged status as victim" (LaCapra, 2001: 81) or their demand for positive discrimination, as happened with the Dalit community when they were labelled as Scheduled Castes by the 1950 Constitution.

\section{CONCLUSION}

Trauma is, without doubt, a ubiquitous aspect in Untouchable as it deals with a community that has endured generational and cyclical discrimination, and has been subjected to violence and humiliation for centuries on account of the Hindu caste system. This institutionalised discrimination was partly due to their poor or, rather, non-existent representation in most fields of Indian society and culture, including literature, which is why the publication of Anand's novel was so important.

The novel displays an individual trauma - revolving around a day full of abuses — as reflective of the Dalit collective trauma. Bakha, the protagonist, acts as a representative of the Dalit community and the atrocities and injustices they have had to endure on a daily basis. Nevertheless, the trauma they suffer does not fit into western classical descriptions of trauma unless a series of adaptations are made, which has led many postcolonial critics to demand that Eurocentric trauma notions should be questioned and expanded, and that the socio-cultural context should always be taken into serious consideration. Therefore, in the case of Dalits we cannot talk about a single shattering and historically identifiable event, but rather about a continuous traumatic existence in which unexpectedness is almost irrelevant. There is hardly any latency or numbness in their case since, although violent events undoubtedly left their marks on their psyche and body, they were forced to internalise their subhuman nature so as to be able to go on with their lives. This constant abuse and discrimination inevitably led to their perpetual state of anxiety and alertness. 
In addition, the novel shows by means of two main different perspectives - that of the old and the young untouchable - that the trauma they suffer does not affect everyone equally and that it is multi-layered — inter/intra-caste discrimination — and multi-faceted as it materialises in many elements, such as place, gender and religion. As a result, in the Dalits' case there is not only a blurring of individual and collective traumata, but also an insidious trauma as their identity as a community has been affected and shattered over time, thus creating a strong sense of fellowship.

As regards the stylistic devices employed in the novel to reflect trauma, the narrative cannot be considered to be experimental or aporetic, despite the several instances of flashbacks, since the events are narrated in a sequential manner which could be a consequence of the author's detachment from this type of atrocities. As for Bakha, he could be considered to be a rather unreliable witness as he suffered this humiliation in his own flesh, which could lead to some collapse of witnessing and biased testimony. However, the fact that he is nonetheless able to narrate it can, in turn, be interpreted as a means to work through his trauma and somehow try to heal the damage inflicted.

Anand makes it clear that collective trauma has left several sequelae, at both a personal and a communal level in the Dalit community, which has thus borne the brunt of severe prejudice and institutionalised discrimination for centuries. Their traumata have not been caused by environmental factors, nor have they been inflicted by a specific person, but, rather, they have their roots in the institutionalisation of the caste system and the endorsement of the most restrictive version of the Hindu religion. Although untouchability was legally abolished with the 1950 Constitution of India — whose drafting was chaired by Bhimrao Ramji Ambedkar, one of India's foremost Dalit revolutionaries - and the condition of Dalits in the cities has in some ways improved, the feeling of caste and birth superiority is still at work, especially in rural areas where the caste infrastructure is still the one that counts. In fact, according to the latest census in 2011 the entire Dalit population in India may exceed 320 million and they are predominantly rural people as the extent of their urbanisation in 2011 was $23.74 \%$ as against $32.42 \%$ for the whole country. Consequently, untouchability is still a fact, and Dalits continue to face mistreatment and violence because of their status. Casteism is by no means completely eradicated and, according to daily news reports, prejudices are still alive and kicking in the twenty-first century. 


\section{WORKS CITED}

ABRAHAM, JOSHIL K. and JUDITH MISRAHI-BARAK (2016). Dalit Literatures in India. New Delhi: Routledge.

AMERICAN PSYCHIATRIC ASSOCIATION (2000). Diagnostic and Statistical Manual, Washington DC: APA, 4th rev.

ANAND, MULK RAJ (2014). Untouchable, London: Penguin Classics.

BROWN, LAURA S. (1995). "Not Outside the Range: One Feminist Perspective on Psychic Trauma", In: Cathy Caruth (ed.) Trauma: Explorations in Memory, Baltimore and London: Johns Hopkins UP: 100-112.

CARUTH, CATHY (1995). Trauma: Explorations in Memory, Baltimore and London: Johns Hopkins UP.

CHANDRA, RAMESH (2005). Identity and Genesis of Caste System in India, New Delhi: Gyan Books.

ERIKSON, KAI (1995). "Notes on Trauma and Community", In: Cathy Caruth (ed.) Trauma: Explorations in Memory, Baltimore MD \& London: Johns Hopkins UP: 183-199.

FELMAN, SHOSHANA (1995). "Education and Crisis, or the Vicissitudes of Teaching", In: Cathy Caruth (ed.) Trauma: Explorations in Memory, Baltimore and London: Johns Hopkins UP: $13-60$.

HERRERO, DOLORES and SONIA BAELO-ALLUÉ (2011). The Splintered Glass: Facets of Trauma in the Post-Colony and Beyond, Amsterdam: Rodopi.

KRYSTAL, HENRY (1995). "Trauma and Aging: a Thirty-Year Follow-Up”, In: Cathy Caruth (ed.) Trauma: Explorations in Memory, Baltimore and London: Johns Hopkins UP: 76-99.

KUMAR, RAJ (2010). Dalit Personal Narratives: Reading Caste, Nation, and Identity, New Delhi: Orient Blackswan.

LACAPRA, DOMINICK (2001). Writing History, Writing Trauma, Baltimore and London: Johns Hopkins UP.

LAUB, DORI (1995). "Truth and Testimony: the Process and the Struggle”, In: Cathy Caruth (ed.) Trauma: Explorations in Memory, Baltimore and London: Johns Hopkins UP: 61-75.

LUCKHURST, ROGER (2013). The Trauma Question, Abingdon: Routledge.

PEDERSON, JOSHUA (2014). "Speak, Trauma: Towards a Revised Understanding of Literary Trauma Theory", Narrative (22): 333-353. 
VALMIKI, OMPRAKASH and ARUN PRABHA MUKHERJEE (2003). Joothan: An Untouchable's Life, New York: Columbia UP.

BIANCA ChEREChÉS is a lecturer at the Department of English and German Philology at the University of Zaragoza, Spain. She is currently enrolled in the doctoral programme offered by the University of Zaragoza and is writing her PhD on "The representation of Dalits in Indian literature written in English". Her current interests are contemporary Indian fiction, trauma and postcolonial studies. 